\title{
Impacts of genetic material and current technologies on product quality of selected greenhouse vegetables - A review
}

\author{
N. Gruda ${ }^{1}$, D. Savvas ${ }^{2}$, G. Colla ${ }^{3}$ and Y. Rouphael ${ }^{4}$ \\ ${ }^{1}$ Division of Horticultural Sciences, Institute of Plant Sciences and Resource Conservation, University of Bonn, Bonn, \\ Germany \\ ${ }^{2}$ Laboratory of Vegetable Production, Agricultural University of Athens, Athens, Greece \\ ${ }^{3}$ Department of Agricultural and Forestry Sciences, University of Tuscia, Viterbo, Italy \\ ${ }^{4}$ Department of Agricultural Sciences, University of Naples Federico II, Portici, Italy
}

\section{Summary}

Product quality is a multi-factorial issue that depends on both pre- and post-harvest factors. Most studies on vegetables consider, however, the influence of postharvest and/or processing factors. Good post-harvest and processing conditions can only retain quality characteristics defined by pre-harvest factors. In addition, greenhouse vegetables are used by consumers as fresh products that are not processed. Thus, it is imperative to maximize quality of greenhouse vegetables through appropriate pre-harvest growing techniques. Here we review the impacts of genetic material and new efficient cultivation technologies and practices on product quality of greenhouse vegetables, referring to studies carried out from the beginning of this century. The major points are the following: (i) due to adapted growing conditions greenhouses provide not only high-value vegetables, high yields, extended cultivation time and earliness but they are also a good tool to improve product quality; (ii) higher quality can be obtained by specific agronomic techniques, such as, e.g., moderate plant stress, adequate plant space and other cultural management; however, these are not to be considered separately but as part of an overarching system. Since product quality does not always correlate with high vegetable yields and vice versa, sometimes compromises need to be made.

Keywords

cultural management, growing techniques, harvest time, mineral nutrition, pre-harvest factors, protected cultivation, salinity, soilless culture

\section{Introduction}

Vegetables provide a variety of health benefits. They are generally low in fat and calories, yet rich in vitamins and dietary fibers. Moreover, they present an important source of mineral nutrients, essential amino acids, antioxidants and phytochemicals such as carotenoids, anthocyanins, flavonoids, and other phenolic compounds, which help counter many common diseases such as blood pressure, diabetes, cancer, vision loss, heart disease, and a number of intestinal disorders (Shahbaz et al., 2014). In addition to several epidemiological studies that promote the positive effects of vegetables and fruits, a recent meta-analysis provides evidence that a consumption of vegetables and fruit - of up to five

\section{Significance of this study}

What is already known on this subject?

- Product quality has been gaining interest in recent horticulture. Product quality and the level of healthy important compounds vary according to plant genetic composition of species and cultivars used, environmental conditions, and developmental stage. However, the effect of growing techniques and cultural practices on product quality have been little studied in greenhouse vegetables.

What are the new findings?

- Several relations, as well as interactions, between genetic composition, fertilizer, and biotechnological applications on one hand and different quality attributes and healthy important compounds, such as contents of nitrate, vitamins and secondary metabolites on the other hand are new and important findings both for the producer and consumer.

What is the expected impact on horticulture?

- The overall impact of this review could be of interest for all actors dealing with product quality and "healthy horticultural produce" and interested in interactions between growing techniques, cultural practices and content of different compounds and metabolites in greenhouse vegetables.

servings a day - is associated with a lower risk of all causes of mortality, especially cardiovascular mortality (Wang et al., 2014).

Product quality is a complex and a multi-factorial issue that depends on several factors and includes both objective, measurable quality traits as well as subjective, sensory characteristics (Gruda, 2005). According to Gianquinto et al. (2013), produce quality may be defined as the degree to which a series of extrinsic or intrinsic characteristics of a given product fulfils the requirements expressed by the consumers. However, product quality parameters are not necessarily consistent with product attributes applied by consumers. Lacking immediate insight into intrinsic product quality parameters (e.g., environmental impact of the cultivation method), consumers' acceptance of vegetable product quality instead is more based on extrinsic product attributes such as price, label or the type of packaging material used (indicating cultivation method, e.g., integrated or organic method 
or origin) and other characteristics generally associated with perception of products within the handling system (Jongen, 2000; Shewfelt and Tijskens, 2000; Schnitzler and Gruda, 2002). This means that consumers form their expectations on intrinsic quality parameters based on cues from extrinsic variables (Schnitzler and Gruda, 2002).

The increasing market demand for high quality yield has lead more and more crop production systems into protected environments (Gruda and Tanny, 2014, 2015). Enclosing the crop with a cover had a beneficial effect on the microclimate. Together with simple means of climate conditions, this allows for an improved food production and quality with higher production levels, extension of the growing season and decreased water use compared to an open-field production (Giacomelli et al., 2008). In response to consumer's trends for healthy and sustainable food, scientific studies showed that phytonutrient levels and profiles of greenhouse vegetables can be directly and indirectly improved by smart growing practices and environmental control (Dorais, 2017).

The current review reports the impacts of different factors such as genetic material, plant nutrition, agronomic practices and cultural management, and time of harvest on the quality of vegetables. Some issues, such as, e.g., environmental factors and climate control, production methods, like conventional, integrated and organic plant production; or, e.g., the type of substrate in soilless culture, water and irrigation, as well as postharvest modification have not been considered in this review.

\section{Impact of genetic material on vegetable quality}

\section{Genotypes and cultivar choice}

Genetic characteristics of plant material are the most important aspects to be considered for optimizing product quality. A number of studies reported cultivar differences in the susceptibility of tomatoes to blossom-end rot (BER) (Ho and Hand, 1997; Cuartero and Fernández-Munõz, 1999; Savvas et al., 2008). For instance, De Kock et al. (1979) reported that the incidence of BER varied from 0.2 to $21.1 \%$ in six tomato cultivars. Differences in product quality characterized by Ca-related disorders have been reported for other vegetables as well (Schnitzler and Gruda, 2002). For instance, the induction of BER in pepper was more pronounced in susceptible cultivars, such as, e.g., 'Evident' and 'Farulia' than in the tolerant ones, such as, e.g., 'Mazurka' (Ho and Hand, 1997). The incidence of tipburn in butterhead lettuce was higher for 'Miranda' than for 'Norden' (Voogt, 1989). Magan et al. (2008) found a notable difference in susceptibility to BER between the two tomato cultivars 'Boludo' and 'Daniela'. As reported by these authors and Savvas et al. (2008), the differences in susceptibility to BER have been related to: (i) fruit growth rate; (ii) the efficiency of Ca-uptake and subsequent translocation of Ca to fruit; and (iii) Ca transport within the fruit and in particular at the distal end.

Physiological behavior, tolerance against different stress reactions and the susceptibility of greenhouse vegetable cultivars to these conditions is expressed not only with variation in terms of external parameters, but also with modification of internal quality. Below are given two examples for one parameter, such as, e.g., lycopene, and the total flavor of tomatoes.

The red color of ripe tomato fruits is attributed to lycopene, a carotenoid synthesized and stored in the chromoplasts (Gruda and Tanny, 2014). This substance is also one of the major antioxidants found in fruits (Dumas et al., 2003). According to the authors, the lycopene concentration in tomato fruits depends on multiple factors. To these belong not only environmental conditions, e.g., temperature and light (increasing from glass to plastic tunnel to field), and technologies used, e.g., water and fertilizer management, but also genetics. Consequently, cultivar choice may strongly influence the result at harvest time. Sometimes variations ranging from more than one- to three-fold have been found (Dumas et al., 2003). Auerswald et al. (1999) carried out a quantitative descriptive analysis of flavor attributes of tomatoes. The intensity of off-flavor attributes, such as moldy, spoiled, sweetish and bitter was more pronounced in the so-called long-life cultivars, such as, e.g., cultivar 'Vanesa' as in the round cultivar 'Counter'.

In conclusion, sources of genetic material and cultivar choice greatly influence product quality of protected crops. Breeders can address these improvements, not only in respect to yield and earliness, but also in respect to external and internal product quality.

\section{Grafting, rootstock genotype and rootstock-scion combinations}

Vegetable grafting, mainly used in Cucurbitaceae and Solanaceae species, is a modern propagation and environment-friendly technology that has been widely used to manage and ameliorate different stress situations. In the following sections the impact of grafting on the qualitative traits that are particularly important for consumer satisfaction such as organoleptic and health-related compounds will be reported and discussed.

The rootstock genotype and the rootstock-scion combination are crucial since they can modify the amounts of hormones synthesized and their influence on flowering order and sex expression of grafted vegetables (Satoh, 1996). Taxonomic affinity is a prerequisite for graft compatibility (Goldschmidt, 2014). Grafting combination could be intraspecific, e.g., tomato/tomato or interspecific, e.g., tomato/eggplants (Abdelmageed and Gruda, 2009). For instance, reduced total soluble solids (TSS) has been demonstrated for diploid watermelon scions grafted onto cashew pumpkin, also known as Japanese pie pumpkin (Cucurbita argyrosperma), and zucchini squash (Cucurbita pepo L.) rootstocks (Kyriacou et al., 2017). A similar trend was also observed in melon fruits of 'Cynaro' (var. cantaloupensis) grafted onto the interspecific hybrid (Cucurbita maxima $\times$ Cucurbita moschata) 'P360' with a decrease in respect to ungrafted plants (Colla et al., 2006a). Similarly, when melon 'Proteo' was used as scion and grafted onto Cucumis metuliferus and Benicasia hyspidia, a lower TSS value was recorded in grafted than in ungrafted plants (Verzera et al., 2014). For tomatoes, lower TSS in fruits harvested from grafted plants could be attributed to different mechanisms: (i) an affected sucrose-metabolizing enzyme; (ii) an increase in fruit water content; and (iii) a reduction of assimilates flow to the fruits due to rootstock vigor (Xu et al., 2006; Martinez-Ballestra et al., 2010). However, reduced levels of TSS in vegetables is not a general effect of grafting and may depend of different production environments, harvest time and especially the rootstock-scion combinations (Rouphael et al., 2010; Kyriacou et al., 2017). For instance, the more common types of commercially rootstocks, particularly Cucurbita hybrids and bottle gourd (Lagenaria siceraria) had no significant effect on the TSS and reduced sugars (glucose, fructose and sucrose) of the watermelon fruit (Davis et al., 2008; Proietti et al., 2008; Rouphael et al., 2008). 
TSS was also not affected for tomatoes (Khah et al., 2006; Savvas et al., 2011) or pepper, when, e.g., 'Edo' and 'Lux' were grafted onto five Capsicum rootstocks ('97.9001', 'DR08801, 'RX360', 'Snooker' and 'Tresor') (Colla et al., 2008) as well as when 'Herminio' were grafted onto the following commercial pepper rootstocks: 'Atlante', 'Creonte' and 'Terrano' (Lopez-Marin et al., 2013). Contrarily, higher TSS was observed with respect of ungrafted plants in melon plants 'Incas' (var. inodorus) grafted onto 'AS10' (Verzera et al., 2014), and also in melon 'Homerunstar' (var. inodorus) grafted onto the interspecific hybrid 'Shintosa' (Jang et al., 2014). Liu et al. (2015) reported similar TSS and titratable acidity (TA) values between self-grafted melon 'Elizabeth' and grafted plants onto Cucumis pustulatus. Moreover, Colla et al. (2012) showed that the TSS contents in cucumber 'Akito' fruits grafted onto 'PS 1313' was higher compared to ungrafted plants, whereas an opposite trend was recorded for TA with a significant decrease in fruits harvest from grafted plants.

Rootstock genotypes and specific rootstock/scion combinations play an crucial role on the content of macro- and microelements and phytochemicals of greenhouse vegetables. Grafting mini-watermelon 'Ingrid' onto the interspecific pumpkin hybrid 'PS1313' positively affected the fruit mineral composition, by increasing $\mathrm{K}$ and $\mathrm{Mg}$ concentrations in the pulp (Rouphael et al., 2008). Similarly, Salehi et al. (2014) observed an increase in fruit $\mathrm{N}, \mathrm{P}$ and $\mathrm{K}$ concentrations of melon cultivar 'Khatooni' grafted onto 'Ace' and 'Shintoza' rootstocks. Moreover, Khah et al. (2006), demonstrated that Ca contents in tomato fruits 'Big Red' was significantly higher in plants grafted onto 'Heman' in comparison to the ungrafted and self-grafted ones. The higher Ca concentration recorded in fruits from grafted plants is ascribed to the increase of water and nutrient uptake resulting from the vigorous root system of the rootstock.

An increase in lutein concentration was observed in fruit samples from melon plants grafted onto the following rootstocks: 'AS10', 'Elsi', 'P360' and 'RS841' (Verzera et al., 2014). Fruit coming from the combinations Incas/P360 and Liyu/ Nanzhen $\mathrm{N}^{\circ} .1$ contained eight- and four-fold more $\beta$-carotene than fruit from ungrafted plants (Verzera et al., 2014; Zhou et al., 2014). However, in the same study when the combinations Incas/Energy and Incas/Sting were adopted, a decrease (about 55\% less than in the control treatment) in the amount of $\beta$-carotene was obtained (Verzera et al., 2014). Similarly Çandir et al. (2013) reported an increase in lycopene content by $11-27 \%$ in watermelon grafted on selected bottle gourd genotypes, as well as in triploid watermelon grafted onto zucchini squash and cushaw pumpkin rootstocks (Davis and Perkins-Veazie, 2005). The lycopene concentration of the tomato 'Jeremy' decreased when it was grafted on rootstocks of 'Maxifort' and 'Beaufort', whereas an opposite trend was observed when the rootstock 'Madonna' was used (Miskovic et al., 2008). Moreover, when pepper cultivars 'Fascinato' and 'Jeanette' were grafted onto the rootstock 'Terrano', the $\beta$-carotene concentration increased whereas the lycopene remained unchanged (Chávez-Mendoza et al., 2013). The apparent absence or even decrease in lycopene concentration in response to grafting could be attributed to the differences in harvest maturity between fruits of grafted and ungrafted plants. A recent work (Soteriou et al., 2014) highlighted that watermelon lycopene concentration was mainly affected by ripening stage while grafting contributed to this only indirectly, by delaying the maturity process.

Sánchez-Rodríguez et al. (2012) used reciprocal grafting between drought-tolerant cultivar 'Zarina' and drought-susceptible cultivar 'Josefina' and found that Josefina/Zarina combination under water stress conditions exhibited the highest concentration of flavonoids, hydroxycinnamic acid and rutein. Similarly, Nicoletto et al. (2013) reported a higher phenolic acid in tomato 'Profitto' grafted onto the rootstocks 'Beaufort' in comparison to ungrafted plants, whereas the phenolic compounds remained unchanged with 'Big power' used as rootstock. Contrarily, Vinkovic-Vreek et al. (2011) reported that grafting reduced the phenolic compounds in tomato fruits 'Tamaris' grafted onto 'Heman', 'Efiato' and 'Maxifort', confirming one more time that the genotype of rootstock and rootstock-scion combinations could significantly affect the quality of fruit in grafted plants (Rouphael et al., 2010).

A positive effect of grafting on vitamin C contents was also observed in pepper when two cultivars, 'Fascinato' and 'Jeanette' were grafted onto the rootstock 'Terrano' (Chávez-Mendoza et al., 2013). In tomato, the ascorbic acid content was highly influenced by the scion/rootstock combination, as shown by Turhan et al. (2011) who reported higher ascorbic acid content with tomato plants grafted onto 'Beaufort' rather than 'Arnold' rootstock.

Aroma volatiles, which play a crucial role in determining fruit flavor, are also influenced by grafting. For instance, the content of key aroma esters ethyl 2-methylbutanoate and ethyl butanoate was by 20 to $95 \%$ less in fruit of melon 'Proteo' grafted onto the rootstocks 'AS10,' 'Energia', 'P360', 'Polifemo' and 'RS841' than in fruit from ungrafted 'Proteo' plants (Verzera et al., 2014). In line with the previous experiment, Yarsi and Sari (2012) reported a decrease in octyl acetate, isobutyl acetate and butyl acetate when melon 'Galia C8' was grafted onto 'RS841' rootstock. In tomato, the concentrations of the three volatile compounds: methyl salicylate (oily), guaiacol (sweetness) and eugenol (spicy) increased, whereas the three aroma volatiles with almoundy odour (benzaldehyde), violet-like odour ( $\beta$-ionone) and tomato-like flavor (geranylacetone) decreased when the two cherry tomato cultivars 'Piccolino' and 'Classy' were grafted onto the rootstocks 'Brigeor' and 'Maxifort' (Krumbein and Schwarz, 2013). Unfortunately, the scarce information does not allow to have a clear picture concerning the effects of grafting on aroma volatiles. Therefore, additional research on the effect of rootstock genotype and rootstock/scion combinations under different growing conditions on aroma volatiles are required to elucidate the bio-physiological mechanism(s) responsible of the change in vegetable flavor compounds.

\section{Impact of major nutrients on product quality}

Agronomic performance of greenhouse crops is related to the technological sophistication level of the greenhouse, its equipment and management. The lowest level is a greenhouse with no other climate control equipment apart from openings for passive ventilation, while the fully equipped greenhouse constitutes the highest level (Giacomelli et al., 2008). Different cultivation and technological practices could be applied. All these factors affect in turn product quality, and crop nutrition is for sure very important among them.

In this section, the impact of current fertilization practices and other cultural treatments related to plant nutrition on vegetable quality is addressed with a briefly review of the impact of individual nutrients on vegetable quality characteristics. 


\section{Impact of nitrogen on vegetable quality}

As reported by Parisi et al. (2006), a high N supply impaired some important quality characteristics of the tomato fruit, such as $\mathrm{pH}$, soluble solids, glucose and fructose content, as well as the ratio of reducing sugars to total solids. An increase of $\mathrm{N}$ up to a certain level may also enhance some nutritional attributes of pepper, such as the concentrations of lycopene and $\beta$-carotene and the antioxidant activity of the lipophilic fraction, as well as its overall commercial quality (Flores et al., 2004). With respect to the form of nitrogen, a $\mathrm{NH}_{4}{ }^{+}-\mathrm{N}$ dominated $\mathrm{N}$ supply may markedly increase the incidence of fruits with blossom-end rot (BER), an effect that is ascribed to a depression of Ca uptake by the enhanced external $\mathrm{NH}_{4}{ }^{+}$levels (Siddiqi et al., 2002; Akl et al., 2003). Siddiqi et al. (2002) and Heeb et al. (2005) state that the supply of $10 \%$ of total $\mathrm{N}$ in the form of $\mathrm{NH}_{4}{ }^{+}(10 \%$ of total $\mathrm{N})$ is capable of enhancing the flavour of the fruits, presumably by elevating glutamine and glutamate levels.

Nitrate is a natural substance that per se is non-toxic to humans; however, it may lead to the formation of nitrite, nitric oxide and N-nitrous compounds, which may have health effects such as methaemoglobinaemia and carcinogenesis. In plants, high levels of nitrate can be found in leaves whereas much lower levels occur in fruits, seeds or root organs. Herbs (such as basil and coriander) and leaf (such as lettuce, spinach and rocket) and stem (such as celery) vegetables are particularly capable of accumulating large amount of nitrate in their edible parts (up to $15-20 \mathrm{~g} \mathrm{~kg}^{-1} \mathrm{FW}$ ). Much lower $\mathrm{NO}_{3}$ contents are generally found in Brassicas, fruit vegetables (with the exception of zucchini and pumpkin), legume pods and green seeds, tubers, bulbs and mushrooms (EFSA, 2008).

High content of vitamin C, typical of many vegetables, may prevent the conversion of nitrate to nitrite in plant tissue and within the human body, thus further reducing the risk of nitrate toxicity. Moreover, it has been found that nitrate metabolites (e.g., nitric oxide) have important physiological roles such as vaso-regulation. On the other hand, in the EU some limits have been laid down to the nitrate content of vegetables for fresh consumption or processing, for instance for the production of baby foods (EC Regulation no. 1881/2006). Limits to nitrate content of other vegetables, including potato have been established in some European countries while no nitrate standards have been introduced in the U.S. (Santamaria, 2006).

Low radiation is the major factor responsible for excessive nitrate accumulation. This explains why nitrate levels in plant tissues tend to be higher in northern countries, during winter and under cover compared to the southern countries, summer and field cultivation, as demonstrated by a study conducted by EFSA (2008). Intriguingly, the limits imposed by EC Regulation of nitrate content of vegetables depend on season and growing system; apparently, agronomic considerations prevailed on health concern.

\section{Impact of potassium on vegetable quality}

A balanced supply of $\mathrm{K}$ enhances the titratable acidity of tomato, thereby considerably improving fruit flavour (Passam et al., 2007). As reported by Savvas et al. (2008), a shortage in K may considerably degrade the flavour of the tomato fruit, which become tasteless. Low levels of K supply to tomato are associated with fruit ripening disorders (Adams, 2002), while adequate K improves lycopene content and consequently fruit colour (Fanasca et al., 2006; Passam et al., 2007). Additionally, an adequate supply of $\mathrm{K}$ to tomato improves tissue firmness of the fruit and consequently fruit preservation (Schnitzler and Gruda, 2002). Nevertheless, excess $\mathrm{K}$ should be avoided, since it may increase the incidence of blossom-end rot (BER) and other physiological disorders related to low Ca translocation to the fruit.

\section{Impact of phosphorus and calcium on vegetable quality}

With respect to the impact of $\mathrm{P}$ on fruit quality, variations in P supply to tomato do not seem to have a strong impact on total soluble solids, $\mathrm{pH}$ and acidity of tomato juice, or fruit colour characteristics (Oke et al., 2005). However, Martuscelli et al. (2014) found an enhancement of firmness, soluble solids, and total carotenoid content in melon fruits when $\mathrm{P}$ rate was increased from 0 to $200 \mathrm{~kg} \mathrm{ha}^{-1}$.

The calcium nutrition of tomato demands special attention because this nutrient is intimately involved in the occurrence of the physiological disorder BER, which may considerably reduce fruit quality and market acceptability (Taylor and Locascio, 2004; Savvas et al., 2008). BER is caused by a local deficiency of Ca in the distal part of the fruit, which results in a disruption of tissue structure in that area (Adams, 2002). Various factors, including the cultivar, the external concentrations of $\mathrm{Ca}, \mathrm{NH}_{4}-\mathrm{N}, \mathrm{K}$, and $\mathrm{Mg}$, salt or water stress, oxygen availability in the root zone, air relative humidity, and air temperature, may aggravate or ameliorate the occurrence of this physiological disorder (Schnitzler and Gruda, 2002). As a result of the involvement of so many factors in the occurrence of BER, no absolute, critical fruit Ca concentration associated with the appearance of this disorder has been identified (Ho and White, 2005). According to Hao and Papadopoulos (2004), the incidence of BER at an external Ca concentration of $3.75 \mathrm{mM}$ increased linearly with increasing $\mathrm{Mg}$ levels in the root zone, while it was not affected by $\mathrm{Mg}$ concentration at $7.5 \mathrm{mM}$ Ca. Nevertheless, as suggested by Ho and White (2005), the manipulation of the nutrient levels in the root zone or the growth environment are not adequately effective measures in reducing BER because they affect apoplastic Ca concentration in fruit tissue indirectly. Therefore, these authors suggest spraying Ca directly on to young fruits in order to prevent BER.

\section{Impact of salinity on vegetable quality}

In addition to the individual nutrients, the total salt concentration in the root zone is a crucial factor for fruit quality. Moderate salinity is widely used to improve product quality and enhance health-promoting substances of tomatoes (Serio et al., 2004; Magán et al., 2008; Wu and Kubota, 2008a), sweet pepper, cucumber (Sonneveld and Van der Burg, 1991; Trajkova et al., 2006), eggplant (Savvas and Lenz, 1994), celery (Pardossi et al., 1999), watermelon (Colla et al., 2006b), as well as zucchini squash (Rouphael et al., 2006).

The favourable effects of salinity on the quality of tomato are mainly an increasing dry matter content, and higher sugar and titratable acid concentrations in the fruit juice. Serio et al. (2004), reported an improvement in organoleptic quality and nutraceutical properties of cherry tomatoes as well as in some other quality parameters, particularly dry matter content, total soluble solids, vitamin C, $\alpha$-tocopherol, and antioxidative potential.

Wu et al. (2004), Krauss et al. (2006) and Fanasca et al. (2006) stated an increase in lycopene concentration of tomatoes exposed to moderate salinity. In a two-year study, Ehret et al. (2013) also reported an increase of antioxidants, such as, e.g., oxygen radical absorbance capacity, $\beta$-carotene, lycopene, and vitamin $\mathrm{C}$ concentrations in greenhouse tomato treated continuously with nutrient solution electrical con- 
ductivities of 2, 4, or $6 \mathrm{dS} \mathrm{m}^{-1}$. However, multiple regressions of antioxidants in relation to EC and climatic factors showed that antioxidants responded more strongly to light and temperature than to EC.

Based on the above data, one might expect that the percentage of tomato fruits graded Class I could be enhanced by increasing salinity. However, nutrient solution salinity restricts the mean weight of tomato fruit and in some cases, the favourable effects of salinity on the percentage of fruits graded Class I may be counteracted by a higher percentage of small fruits and fruits with BER, as has been reported by Chrétien et al. (2000). The short-term effect of high salinity was a reduced uptake of calcium by the roots and less movement of calcium from the roots to the fruit. The long-term effect may be a reduction in development of xylem tissue within the fruit, as well as calcium movement in the tomato berry, particularly the distal half (Ho and White, 2005). Furthermore, even if there are some inconsistencies in the literature regarding the contribution of salinity to either number of fruits or fruit size, a reduction of tomato fruit yield due to a negative impact in physiological processes is mostly the case. As Shahbaz et al. (2014) reviewed, salinity stress can cause an alteration in a variety of morphological attributes and a decrease of almost all growth parameters, yield, and some yield quality attributes. In conclusion, moderate water or salinity stress may be a feasible cultural management option for producing high-quality greenhouse vegetables particularly in soilless culture. Since quality improvement is sometimes associated with yield reductions, a compromise is needed to find the sectio divina. This depends on the stress level, applied time in relation to growth stage, genetic material used and environmental conditions (Gruda and Tanny, 2014; Dong et al., 2018).

Moreover, the presence of plant biostimulants such as humic substances, protein hydrolysates, seaweed extracts and beneficial microbials, such as mycorrhizal fungi and $\mathrm{N}_{2}$ fixation bacteria, can improve the quality, e.g., by inducing the accumulation of secondary metabolites, vitamins, antioxidants, and minerals (Baum et al., 2015; Colla et al., 2015, 2017; Rouphael et al., 2015). Rouphael et al. (2017) reported an increase in total soluble solids and lycopene content in two greenhouse tomato cultivars periodically sprayed with a plant-derived protein hydrolysate. Moreover, Cardarelli et al. (2010) found an increase of K content and total soluble solids in zucchini fruits from mycorrhized plants with a Glomus intraradices. The above findings suggest that plant biostimulants may be used to improve product quality of vegetables in a sustainable way.

\section{Impact of cropping systems and cultural practices on vegetable quality}

\section{Soilless culture}

From an agronomic point of view, greenhouse production suffers from the repercussions of monoculture, excessive fertilization, and soil-borne pathogens. Soilless culture uses fertigation systems and provides an important tool to overcome these problems, and further to amend plant growth, yield, earliness and quality (Savvas and Gruda, 2018). As Gruda (2009) stated, using soilless cultures systems does not automatically have a consequence on high quality. Numerous studies confirm that this method enables growers to produce vegetables without quality loss compared to soil cultivation. These results are comprehensively reviewed by Gruda (2009), and Lorenzo et al. (2013).
However, some consumers are rather mistrustful with the vegetables produced in soilless culture. This attitude is mainly based on the assumption that the soilless cultivation of plants is based on the extensive use of "chemicals," in contrast to plants grown in soil that acquire "natural substances" (Gruda et al., 2016). It is well known that higher plants need inorganic substances, mainly in ionic form, to satisfy their nutritional requirements (Marschner, 2012). Thus, for instance, plants take up nitrogen $(\mathrm{N})$ as $\mathrm{NO}_{3}{ }^{-}$and $\mathrm{NH}_{4}{ }^{+}$. Any possible uptake of $\mathrm{N}$ in organic forms, e.g., amino acids, has a minor contribution to plant $\mathrm{N}$ nutrition. Consequently, with respect to the quality of edible vegetable products, it is irrelevant whether the $\mathrm{N}$ contained in the plant tissues stems from organic substances of the soil or from inorganic fertilizers (Savvas, 2001; Gruda et al., 2016).

Both the quantity of absorbed nitrogen and the way in which it is utilized in plant metabolism, mainly with respect to the nitrate nitrogen content in the edible plant tissues are better managed in hydroponics (Gruda, 2009; Colla et al., 2018). Thus, as reported by Gonnella et al. (2004), the replacement of the nutrient solution with rain water three days before harvesting resulted in one third of the nitrate reduction in leaves. More information concerning the impact of soilless culture on product quality of greenhouse vegetables is given by Schnitzler and Gruda (2002, 2003), and Gruda (2009).

\section{Cultivating system and growing regime, pruning and support}

Greenhouse production is very intensive and requires a high amount of labor; much of it is manual labor. For instance, in tomatoes, several manual operations such as, e.g., removing axillary shoots, deleafing, truss pruning, and lowering are performed in a steady manner. For instance, deleafing, which consists of removing the oldest leaves that are no longer photosynthetically active, avoids plant diseases and facilitates harvesting. Truss pruning adapts the fruit load to assimilate production, in order to improve fruit grade and quality (Navarrete and Jeannequin, 2000).

In addition, training is applied to indeterminate vegetable crops such as tomato, pepper, and cucumber. Here the main objective is to improve light interception of leaves. This is realized through a combination of plant density and pruning (Savvas et al., 2013; Gruda and Tanny, 2014). With an adequate training system and environmental conditions, spring cropping of tomatoes can be extended to one-crop-per-year. However, in areas with hot summers, a two- or a multi-cropsper-year production strategy is applied. It is well known, that, at the end of a season with year-round crops such as, e.g., tomatoes, product quality decreases. A possible solution is the development of a multi-planting system several times during the growing season. Logendra et al. (2001) designed a single-cluster hydroponic tomato production system for continuous year-round production, with as many as five crops per year. The authors list the benefits of such systems, e.g., supply continuity with a premium paid even in year-times when it is difficult to have the product, easier accessibility and better automation for different cultural practices, as well as better space and light utilization.

An increase in plant density generally correlates positively with yield. However it correlates negatively with the proportion of the marketable yield. The reason for higher yields is a greater photosynthetic photon flux density interception, due to an increase of the total available assimilates for distribution to vegetable fruits (Papadopoulos and Pararajas- 
ingham, 1997). The size reduction of the marketable plant parts and the insufficient supply of photo-assimilates caused mainly due to a competition for light interception, influence the photosynthetic rate and carbohydrate distribution (Gruda and Tanny, 2014). As Gonnella et al. (2003) stated, the definition of optimal plant density for greenhouse vegetables is imperative to obtain high yield and quality levels of products; e.g., for vegetables grown in a floating system especially referring to leaf height, crunchiness and nitrate content. Heuvelink and González-Real (2008) therefore recommend plant densities related to cultivating seasons: typically a tomato crop in the Netherlands has a planting stem density of 2.5 plants $\mathrm{m}^{-2}-$ in the summer, when radiation availability is higher, stem density is increased by $50 \%$ to 3.75 stems $\mathrm{m}^{-2}$.

Pruning is an operation used to support training, with the aim of improving light relationships, equilibrating plant growth and development, providing better control of diseases to minimize yield losses, and improving product quality (Gruda and Tanny, 2014), e.g., within appropriate commercial fruit or organ size. For an adequate pruning environment, other growing conditions have to be taken into account as well. Wrong pruning, such as, e.g., a higher quantity of cucumbers fruit will lead to pushing-off of young fruits, even if the plants are well supplied with nutrients. According to Hanna (2009), pruning clusters to three fruit increased total marketable yield and fruit weight of different greenhouse tomatoes cultivars, cultivated in different growing media in two successive seasons.

\section{Harvest time}

Harvest time is directly related to the ripening stage and therefore very closely linked to product quality. The most vegetables are non-climacteric, although this term is mostly used for fruits. Therefore, most vegetables are not associated with increases in ethylene production and post-harvest cellular respiration. However, tomato, as a climacteric fruit, can be harvested before the ripening stage and subsequently room-ripened. Already in the 70's, Lee (1974) stated that during ripening, total solids and reducing sugars increased while total acid decreased in tomato. Hence, tomatoes picked at the vine-ripe red stage are sweeter, less sour and have more aroma than tomatoes picked at earlier stages. On the other hand, during the ripening, chlorophyll content is reduced and disappeared completely at the beginning of the pink stage in greenhouse tomatoes. During the same period, $\beta$-carotene content doubled. At the ripe-red stage, lycopene constituted $95 \%$ of the colored carotenoids, or $73 \%$ of total carotenoids (Dumas et al., 2002, 2003). Vitamin C, phenolic compounds and carotenoids increased also during ripening of sweet peppers, having higher contents of these bioactive compounds in red pepper (Pérez-López et al., 2007).

Finally yet importantly, harvest time is critical in quality studies. Thus, the appropriate time of analysis for any given parameter is crucial. For instance, as Wu and Kubota (2008a) stated, for a better understanding of lycopene synthesis, lycopene analysis should be done throughout the fruit ripening process from late green to the fully ripened stage rather than at the last stage of ripeness, since lycopene concentration in the tomato fruit increases rapidly during the process (Gruda and Tanny, 2014).

\section{Conclusion and outlook}

Product quality is related to different factors which affect agronomic performance of crops. All technology chain links should be considered. Better quality can be obtained by direct measures, such as, e.g., moderate water and salinity stress, adequate plant space and other cultural management. The technology chain links are not to be considered separately but as part of an overarching system. The interactions among them and environmental conditions influence product quality. As Giacomelli et al. (2008) stated, advances in greenhouse system design and management require at least to some degree a multi-disciplinary approach of the horticultural sciences, engineering and economics.

Since product quality is not always associated with high yields and vice versa, sometimes compromises have to be made. On the other hand, valuable high-quality greenhouse products have to fit expectations of producers, traders and consumers and be in balance with environmental goals and the demand of the next generations. With regard to possible climate change, adaptive strategies have to be applied for a sustainable production and a high product quality. As Bisbis et al. (2018) stated, these include among others an effective risk management by meeting the problems of breeding new cultivars and stimulating new ideas in innovative technologies.

\section{References}

Abdelmageed, A.H.A., and Gruda, N. (2009). Influence of grafting on growth, development and some physiological parameters of tomatoes under controlled heat stress conditions. Eur. J. Hortic. Sci. $74,16-20$.

Adams, P. (2002). Nutritional control in hydroponics. In Hydroponic Production of Vegetables and Ornamentals, D. Savvas, and H.C. Passam, eds. (Athens, Greece: Embryo Publications), p. 211-261.

Akl, I.A., Savvas, D., Papadantonakis, N., Lydakis-Simantiris, N., and Kefalas, P. (2003). Influence of ammonium to total nitrogen supply ratio on growth, yield and fruit quality of tomato grown in a closed hydroponic system. Eur. J. Hortic. Sci. 68, 204-211.

Auerswald, H., Schwarz, D., Kornelson, C., Krumbein, A., and Brückner, B. (1999). Sensory analysis, sugar and acid content of tomato at different EC values of the nutrient solution. Sci. Hortic. 82, 227-242. https://doi.org/10.1016/s0304-4238(99)00058-8.

Baum, C., El-Tohamy, W., and Gruda, N. (2015). Increasing the productivity and product quality of vegetable crops using arbuscular mycorrhizal fungi: A review. Sci. Hortic. 187, 131-141. https://doi. org/10.1016/j.scienta.2015.03.002.

Bisbis, M.B., Gruda, N., and Blanke, M. (2018). Potential impacts of climate change on vegetable production and product quality - A review. J. Cleaner Prod. 170, 1602-1620. https://doi. org/10.1016/j.jclepro.2017.09.224.

Çandir, E., Yetişir, H., Karaca, F., and Üstün, D. (2013). Phytochemical characteristics of grafted watermelon on different bottle gourds (Lagenaria siceraria) collected from the Mediterranean region of Turkey. Turkish J. Agric. For. 37, 443-456. https://doi.org/10.3906/ tar-1207-21.

Cardarelli, M., Rouphael, Y., Rea, E., and Colla, G. (2010). Mitigation of alkaline stress by arbuscular mycorrhiza in zucchini plants grown under mineral and organic fertilization. J. Plant Nutr. Soil Sci. 173, 778-787. https://doi.org/10.1002/jpln.200900378.

Chávez-Mendoza, C., Sánchez, E., Carvajal-Millán, E., MuñozMárquez, E., and Guevara-Aguilar, A. (2013). Characterization of the nutraceutical quality and antioxidant activity in bell pepper in response to grafting. Molecules 18, 15689-15703. https://doi. org/10.3390/molecules181215689.

Chretien, S., Gosselin, A., and Dorais, M. (2000). High electrical conductivity and radiation-based water management improve fruit quality of greenhouse tomatoes grown in rockwool. HortSci. 25, 627-631. 
Colla, G., Rouphael, Y., Cardarelli, M., Massa, D., Salerno, A., and Rea, E. (2006a). Yield, fruit quality and mineral composition of grafted melon plants grown under saline conditions. J. Hort. Sci. Biotechnol. 81,146-152. https://doi.org/10.1080/14620316.2006.11512041.

Colla, G., Rouphael, Y., Cardarelli, M., and Rea, E. (2006b). Effect of salinity on yield, fruit quality, leaf gas exchange, and mineral composition of grafted watermelon plants. HortScience 41, 622-627.

Colla, G., Rouphael, Y., Cardarelli, M., Temperini, O., Rea, E., Salerno, A., and Pierandrei, F. (2008). Influence of grafting on yield and fruit quality of pepper (Capsicum annuum L.) grown under greenhouse conditions. Acta Hortic. 782, 359-363. https://doi.org/10.17660/ actahortic.2008.782.45

Colla, G., Rouphael, Y., Rea, E., and Cardarelli, M. (2012). Grafting cucumber plants enhance tolerance to sodium chloride and sulphate salinization. Sci. Hortic. 135, 177-185. https://doi.org/10.1016/j. scienta.2011.11.023.

Colla, G., Nardi, S., Cardarelli, M., Ertani, A., Lucini, L., Canaguier, R., and Rouphael, Y. (2015). Protein hydrolysates as biostimulants in horticulture. Sci. Hortic. 196, 28-38. https://doi.org/10.1016/j. scienta.2015.08.037.

Colla, G., Kim, H.J., Kyriacou, M., and Rouphael, Y. (2018). Nitrates in fruits and vegetables. Sci. Hortic. 237, 221-238. https://doi. org/10.1016/j.scienta.2018.04.016.

Cuartero, J., and Fernández-Munõz, R. (1999). Tomato and salinity. Sci. Hortic. 78, 83-125. https://doi.org/10.1016/S03044238(98)00191-5.

Davis, A.R., and Perkins-Veazie, P. (2005). Rootstock effects on plant vigor and watermelon fruit quality. Cucurbit Genet. Coop. Rpt. 28, 39-42.

Davis, A.R., Perkins-Veazie, P., Sakata, Y., López-Galarza, S., Maroto, J.V., Lee, S.G., Huh, Y.C., Sun, Z., Miguel, A., King, S.R., Cohen, R., and Lee, J.M. (2008). Cucurbit grafting. Crit. Rev. Plant Sci. 27, 50-74. https://doi.org/10.1080/07352680802053940.

De Kock, P.C., Hall, A., Inkson, R.H.E., and Robertson, R.A. (1979). Blossom-end rot in tomatoes. J. Sci. Food Agric. 30, 508-514. https:// doi.org/10.1002/jsfa.2740300511.

Dong, J., Gruda, N., Lam, S.K., Liu, X., and Duan, Z. (2018). Effects of elevated $\mathrm{CO}_{2}$ on nutritional quality of vegetables - A review. Front. Plant Sci. 9, 924. https://doi.org/10.3389/fpls.2018.00924.

Dorais, M. (2017). Revisiting the concept of quality improvement of greenhouse products. Greensys 2017 - Int. Symp. 'New technologies for environment control, energy-saving and crop production in greenhouse and plant factory'. Program \& Abstract, August 20-24.

Dumas, Y., Dadomo, M., Di Lucca, G., and Grolier, P. (2002). Review of the influence of major environmental and agronomic factors on the lycopene content of tomato fruit. Acta Hortic. 579, 595-601. https:// doi.org/10.17660/actahortic.2002.579.105.

Dumas, Y., Dadomo, M., Di Lucca, G., and Grolier, P. (2003). Effects of environmental factors and agricultural techniques on antioxidant content of tomatoes. J. Sci. Food Agric. 83, 369-382. https://doi. org/10.1002/jsfa.1370.

EFSA (2008). Nitrate in vegetables: scientific opinion of the panel on contaminants in the food chain. EFSA J. 689, 1-79. https://doi. org/10.2903/j.efsa.2008.689.

Ehret, D.L., Usher, K., Helmer, T., Block, G., Steinke, D., Frey, B., Kuang, T., and Diarra, M. (2013). Tomato fruit antioxidants in relation to salinity and greenhouse climate. J. Agric. Food Chem. 61, 1138-1145. https://doi.org/10.1021/jf304660d.

Fanasca, S., Colla, G., Maiani, G., Venneria, E., Rouphael, Y., Azzini, E., and Saccardo, F. (2006). Changes in antioxidant content of tomato fruits in response to cultivar and nutrient solution composition. J. Agric. Food Chem. 54, 4319-4325. https://doi.org/10.1021/jf0602572.
Flores, P., Navarro, J.M., Garrido, C., Rubio, J.S., and Martínez, V. (2004). Influence of $\mathrm{Ca}^{2+}, \mathrm{K}^{+}$and $\mathrm{NO}_{3}$ - fertilisation on nutritional quality of pepper. J. Sci. Food Agric. 84, 569-574. https://doi. org/10.1002/jsfa.1694.

Giacomelli, G., Castilla, N., Van Henten, E., Mears, D., and Sase, S. (2008). Innovation in greenhouse engineering. Acta Hortic. 801, 75-88. https://doi.org/10.17660/actahortic.2008.801.3.

Gianquinto, G., Muñoz, P., Pardossi, A., Ramazzotti, S., and Savvas, D. (2013). Soil fertility and plant nutrition. In Good Agricultural Practices for Greenhouse Vegetable Crops - Principles for Mediterranean Climate Areas. Plant Production and Protection Paper No. 217, (Rome, Italy: Food and Agriculture Organization of the United Nations (FAO)), p. 205-268.

Goldschmidt, E.E. (2014). Plant grafting: new mechanisms, evolutionary implications. Front Plant Sci. 5, 727. https://doi. org/10.3389/fpls.2014.00727.

Gonnella, M., Serio, F., Conversa, G., and Santamaria, P. (2003). Yield and quality of lettuce grown in floating system using different sowing density and plant spatial arrangements. Acta Hortic. 614, 687-692. https://doi.org/10.17660/actahortic.2003.614.102.

Gonnella, M., Serio, F., Conversa, G., and Santamaria, P. (2004). Production and nitrate content in lamb's lettuce grown in floating system. Acta Hortic. 644, 61-68. https://doi.org/10.17660/ ActaHortic.2004.644.5.

Gruda, N. (2005). Impact of environmental factors on product quality of greenhouse vegetables for fresh consumption. Crit. Rev. Plant Sci. 24, 227-247. https://doi.org/10.1080/07352680591008628.

Gruda, N. (2009). Do soilless culture systems have an influence on product quality of vegetables? J. Appl. Bot. Food Qual. 82, 141-147.

Gruda, N., and Tanny, J. (2014). Protected Crops. In Horticulture Plants for People and Places, Vol. 1: Production Horticulture, Ch. 10, G.R. Dixon, and D.E. Aldous, eds. (Dordrecht, the Netherlands: Springer Science+Business Media), p. 327-405. https://doi. org/10.1007/978-94-017-8578-5_10.

Gruda, N., and Tanny, J. (2015). Protected crops - Recent advances, innovative technologies and future challenges. Acta Hortic. 1107, 271-278. https://doi.org/10.17660/actahortic.2015.1107.37.

Gruda, N., Gianquinto, G., Tüzel, Y., and Savvas, D. (2016). Culture Soil-less. In Encyclopedia of Soil Sciences, $3^{\text {rd }}$ edn., R. Lal, ed. (CRC Press, Taylor \& Francis Group), p. 533-537. ISBN 9781498738903.

Hanna, H.Y. (2009). Influence of cultivar, growing media, and cluster pruning on greenhouse tomato yield and fruit quality. HortTechn. 19, 395-399.

Hao, X., and Papadopoulos, A.P. (2004). Effects of electrical conductivity and mineral nutrition on fruit radial. Acta Hortic. 633, 365-372.

Heeb, A., Lundegårdh, B., Ericsson, T., and Savage, G.P. (2005). Effects of nitrate-, ammonium-, and organic-nitrogen-based fertilizers on growth and yield of tomatoes. J. Plant Nutr. and Soil Sci. 168, 123129. https://doi.org/10.1002/jpln.200420420.

Heuvelink, E., and González-Real, M.M. (2008). Innovation in plantgreenhouse interactions and crop management. Acta Hortic. 801, 63-74. https://doi.org/10.17660/actahortic.2008.801.2.

Ho, L.C., and Hand, D.J. (1997). Cultivar and cultural aspects of the prevention of blossom-end rot in tomato and pepper. $9^{\text {th }}$ Intern. Congr. Soilless Culture, St. Helier, Jersey, 1996 (Wageningen, the Netherlands: ISOSC), p. 197-205.

Ho, L.C., and White, P.J. (2005). A cellular hypothesis for the induction of blossom-end rot in tomato fruit. Ann. Bot. 95, 571-581. https:// doi.org/10.1093/aob/mci065. 
Jang, Y., Huh, Y.C., Dong-Kum, P., Mun, B., Lee, S., and Um, Y. (2014). Evaluation of melon rootstock resistance to monosporascus root rot and vine decline as well as of yield and fruit quality in grafted 'Inodorus' melons. Korean Soc. Hortic. Sci. 32, 614-622. https://doi. org/10.7235/hort.2014.14065.

Jongen, W.M.F. (2000). Food supply chains: from productivity toward quality. In Fruit and Vegetable Quality: an Integrated View, R.L. Shewfelt, and B. Bruckner, eds. (CRC Press), p. 320-330.

Khah, E.M., Kakava, E., Mavromatis, A., Chachalis, D., and Goulas, C. (2006). Effect of grafting on growth and yield of tomato (Lycopersicum esculentum Mill.) in greenhouse and open-field. J. Appl. Hortic. 8, 3-7.

Krauss, S., Schnitzler, W.H., Grassmann, J., and Woitke, M. (2006). The influence of different electrical conductivity values in a simplified recirculating soilless system on inner and outer fruit quality characteristics of tomato. J. Agric. Food Chem. 54, 441-448. https:// doi.org/10.1021/jf051930a.

Krumbein, A., and Schwarz, D. (2013). Grafting: A possibility to enhance health-promoting and flavour compounds in tomato fruits of shaded plants? Sci. Hortic. 149, 97-107. https://doi.org/10.1016/j. scienta.2012.09.003.

Kyriacou, M.C., Rouphael, Y., Colla, G., Zrenner, R.M., and Schwarz, D. (2017). Vegetable grafting: The implications of a growing agronomic imperative for vegetable fruit quality and nutritive value. Front. Plant Sci. 8, 741. https://doi.org/ 10.3389/fpls.2017.00741.

Lee, C.Y. (1974). Effect of cultural practices on chemical composition of processing vegetables. A review. Appl. Sci. Engin. 39, 1075-1079. https://doi.org/10.1111/j.1365-2621.1974.tb07322.x.

Liu, B., Ren, J., Zhang, Y., An, J., Chen, M., Chen, H., Xu, Ch., and Ren, H. (2015). A new grafted rootstock against root-knot nematode for cucumber, melon, and watermelon. J. Agric. Food Chem. 62, 10504-10514. https://doi.org/10.1007/s13593-014-0234-5.

Logendra, L.S., Gianfagna, T.J., Specca, D.R., and Janes, H.W. (2001). Greenhouse tomato limited cluster production systems: Crop management practices affect yield. HortScience 36, 893-896.

López-Marin, J., González, A., Pérez-Alfocea, F., Egea-Gilabert, C., and Fernandez, J.A. (2013). Grafting is an efficient alternative to shading screens to alleviate thermal stress in greenhouse-grown sweet pepper. Sci. Hortic. 149, 39-46. https://doi.org/10.1016/j. scienta.2012.02.034

Lorenzo, R.D., Pisciotta, A., Santamaria, P., and Scariot, V. (2013) From soil to soil-less in horticulture: quality and typicity. Italian J. Agron. 8, 255-260. https://doi.org/10.4081/ija.2013.e30.

Magán, J.J., Gallardo, M., Thompson, R.B., and Lorenzo, P. (2008). Effects of salinity on fruit yield and quality of tomato grown in soilless culture in greenhouses in Mediterranean climatic conditions. Agri. Water Mgt. 95, 1041-1055. https://doi.org/10.1016/j. agwat.2008.03.011

Marschner, P. (2012). Marschner's Mineral Nutrition of Higher Plants (Academic Press, Elsevier), 651 pp.

Martinez-Ballesta, M.C., Alcaraz-Lopez, C., Muries, B., Mota-Cadenas, C., and Carvajal, M. (2010). Physiological aspects of rootstock scion interactions. Sci. Hortic. 127, 112-118. https://doi.org/10.1016/j. scienta.2010.08.002

Martuscelli, M., Di Mattia, C., Stagnari, F., Speca, S., Pisante, M., and Mastrocola, D. (2014). Influence of phosphorus management on melon (Cucumis melo L.) fruit quality. J. Sci. Food Agric. 96, 27152722. https://doi.org/10.1002/jsfa.7390.

Miskovic, A., Ilin, Z., and Markovic, V. (2008). Effect of different rootstock type on quality and yield of tomato fruits. Acta Hortic. 807, 619-622. https://doi.org/10.17660/actahortic.2009.807.92.
Navarrete, M., and Jeannequin, B. (2000). Effect of frequency of axillary bud pruning on vegetative growth and fruit yield in greenhouse tomato crops. Sci. Hortic. 86, 197-210. https://doi. org/10.1016/s0304-4238(00)00147-3.

Nicoletto, C., Tosini, F., and Sambo, P. (2013). Effect of grafting and ripening conditions on some qualitative traits of 'Cuore di bue' tomato fruits. J. Sci. Food and Agric. 93, 1397-1403. https://doi. org/10.1002/jsfa.5906.

Oke, M., Ahn, T., Schofield, A., and Paliyath, G. (2005). Effects of phosphorus fertilizer supplementation on processing quality and functional food ingredients in tomato. J. Agric. Food Chem. 53, 15311538. https://doi.org/10.1021/jf0402476.

Papadopoulos, A.P., and Pararajasingham, S. (1997). The influence of plant spacing on light interception and use in greenhouse tomato (Lycopersicon esculentum Mill.): A review. Sci. Hortic. 69, 1-29. https://doi.org/10.1016/s0304-4238(96)00983-1.

Pardossi, A., Bagnoli, G., Malorgio, F., Campiotti, C.A., and Tognoni, F. (1999). $\mathrm{NaCl}$ effects on celery (Apium graveolens L.) grown in NFT. Sci. Hortic. 81, 229-242. https://doi.org/10.1016/s03044238(99)00020-5.

Parisi, M., Giordano, L., Pentangelo, A., D’Onofrio, B., and Villari, G. (2006). Effects of different levels of nitrogen fertilization on yield and fruit quality in processing tomato. Acta Hortic. 700, 129-132. https://doi.org/10.17660/actahortic.2006.700.19.

Passam, H.C., Karapanos, I.C., Bebeli, P.J., and Savvas, D. (2007). A review of recent research on tomato nutrition, breeding and postharvest technology with reference to fruit quality. Eur. J. Plant Sci. Biotechnol. 1, 1-21.

Pérez-López, A.J., del Amor, F.M., Serrano-Martínez, A., Fortea, M.I., and Núñez-Delicado, E. (2007). Influence of agricultural practices on the quality of sweet pepper fruits as affected by the maturity stage. J. Sci. Food Agric. 87, 2075-2080. https://doi.org/10.1002/jsfa.2966.

Proietti, S., Rouphael, Y., Colla, G., Cardarelli, M., De Agazio, M., Zacchini, M., Rea, E., Moscatello, S., and Battistelli, A. (2008). Fruit quality of mini-watermelon as affected by grafting and irrigation regimes. J. Sci. Food and Agric. 88, 1107-1114. https://doi. org/10.1002/jsfa.3207.

Rouphael, Y., Cardarelli, M., Rea, E., Battistelli, A., and Colla, G. (2006). Comparison of the subirrigation and drip-irrigation systems for greenhouse zucchini squash production using saline and nonsaline nutrient solutions. Agric. Water Mgt. 82, 99-117. https://doi. org/10.1016/j.agwat.2005.07.018.

Rouphael, Y., Cardarelli, M., Colla, G., and Rea, E. (2008). Yield, mineral composition, water relations, and water use efficiency of grafted miniwatermelon plants under deficit irrigation. HortScience 43, 730-736.

Rouphael, Y., Schwarz, D., Krumbein, A., and Colla, G. (2010). Impact of grafting on product quality of fruit vegetables. Sci. Hortic. 127, 172-179. https://doi.org/10.1016/j.scienta.2010.09.001.

Rouphael, Y., Franken, P., Schneider, C., Schwarz, D., Giovannetti, M., Agnolucci, M., De Pascale, S., Bonini, P., and Colla, G. (2015). Arbuscular mycorrhizal fungi act as biostimulants in horticultural crops. Sci. Hortic. 196, 91-108. https://doi.org/10.1016/j. scienta.2015.09.002

Rouphael, Y., Colla, G., Giordano, M., El-Nakhel, C., Kyriacou, M.C., and De Pascale, S. (2017). Foliar applications of a legume-derived protein hydrolysate elicit dose dependent increases of growth, leaf mineral composition, yield and fruit quality in two greenhouse tomato cultivars. Sci. Hortic. 226, 353-360. https://doi.org/10.1016/j. scienta.2017.09.007

Salehi, R., Kashi, A., Lee, J., and Javanpour, R. (2014). Mineral concentration, sugar content and yield of Iranian 'Khatooni' melon affected by grafting, pruning and thinning. J. Plant Nutr. 37, 12551268. https://doi.org/10.1080/01904167.2014.888740. 
Sánchez-Rodríguez, E., Ruiz, J.M., Ferreres, F., and Moreno, D.A. (2012). Phenolic profiles of cherry tomatoes as influenced by hydric stress and rootstock technique. Food Chem. 134, 775-782. https:// doi.org/10.1016/j.foodchem.2012.02.180.

Santamaria, P. (2006). Nitrate in vegetables: toxicity, content, intake and EC regulation. J. Sci. Food Agric. 86, 10-17. https://doi. $\operatorname{org} / 10.1002 /$ jsfa.2351.

Satoh, S. (1996). Inhibition of flowering of cucumber grafted on rooted squash rootstocks. Physiol. Plant. 97, 440-444. https://doi. org/10.1034/j.1399-3054.1996.970304.x.

Savvas, D. (2001). Nutritional management of vegetables and ornamental plants in hydroponics. In Crop Management and Postharvest Handling of Horticultural Products, Vol. I, R. Dris, R. Niskanen, and S.M. Jain, eds. (Enfield, N.H., USA: Quality Management Science Publishers), p. 37-87.

Savvas, D., and Gruda, N. (2018). Application of soilless culture technologies in the modern greenhouse industry - A review. Europ. J. Hortic. Sci. 83(5), 280-293.

Savvas, D., and Lenz, F. (1994). Influence of salinity on the incidence of the physiological disorder 'internal fruit rot' in hydroponicallygrown eggplants. J. App. Bot. 68, 32-35.

Savvas, D., Gianquinto, G., Tüzel, Y., and Gruda, N. (2013). Soilless culture. In Good Agricultural Practices for Greenhouse Vegetable Crops - Principles for Mediterranean Climate Areas., Plant Production and Protection Paper 217, Ch. 12 (Rome, Italy: Food and Agriculture Organization of the United Nations (FAO)), p. 303-354, ISBN 978-92-5-107649-1 (print); E-ISBN 978-92-5-107650-7.

Savvas, D., Ntatsi, G., and Passam, H.C. (2008). Plant nutrition and physiological disorders in greenhouse grown tomato, pepper and eggplant. Eur. J. Plant Sci. Biotechnol. 2, 45-61.

Savvas, D., Savva, A., Ntatsi, G., Ropokis, A., Karapanos, I., Krumbein, A., and Olympios, A. (2011). Effects of three commercial rootstocks on mineral nutrition, fruit yield, and quality of salinized tomato. J. Soil Sci. Plant Nutr. 174, 154-162. https://doi.org/10.1002/ jpln.201000099.

Schnitzler, W.H., and Gruda, N. (2002). Hydroponics and product quality. In Hydroponic Production of Vegetables and Ornamentals, D. Savvas, and H.C. Passam, eds. (Athens, Greece: Embryo Publications), p. 373-411.

Schnitzler, W.H., and Gruda, N. (2003). Quality issues of greenhouse production. Acta Hortic. 614, 663-674. https://doi.org/10.17660/ ActaHortic.2003.614.99.

Serio, F., Gara, L., Caretto, S., Leo, L., and Santamaria, P. (2004). Influence of an increased $\mathrm{NaCl}$ concentration on yield and quality of cherry tomato grown in posidonia (Posidonia oceanica L. Delile). J. Sci. Food Agric. 84, 1885-1890.https://doi.org/10.1002/jsfa.1883.

Shahbaz, M., Ashraf, M., Al-Qurainy, F., and Harris, P.J.C. (2014). Salt tolerance in selected vegetable crops. Crit. Rev. Plant Sci. 31, 303320. https://doi.org/10.1080/07352689.2012.656496.

Shewfelt, R.L., and Tijskens, L.M.M. (2000). A more integrated view. Environmental effects on product quality. In Fruit and Vegetable Quality, R.L. Shewfelt, and B. Brückner, eds. (Lancaster, Basel: Technomic Publishing Co., Inc.), p. 296-306.

Siddiqi, M.Y., Malhotra, B., Min, X., and Glass, A.D.M. (2002). Effects of ammonium and inorganic carbon enrichment on growth and yield of a hydroponic tomato crop. J. Plant Nutr. Soil Sci. 165, 191-197. https://doi.org/10.1002/1522-2624(200204)165:2<191::aidjpln191>3.0.co;2-d.

Sonneveld, C., and Van der Burg, A.M. (1991). Sodium chloride salinity in fruit vegetable crops in soilless culture. Neth. J. Agr. Sci. $39,115-122$
Soteriou, G.A., Kyriacou, M.C., Siomos, A.S., and Gerasopoulos, D. (2014). Evolution of watermelon fruit physicochemical and phytochemical composition during ripening as affected by grafting. Food Chem. 165, 282-289. https://doi.org/10.1016/j. foodchem.2014.04.120.

Taylor, M.D., and Locascio, S.J. (2004). Blossom-end rot: a calcium deficiency. J. Plant Nutr. 27, 123-139. https://doi.org/10.1081/pln120027551.

Trajkova, F., Papadantonakis, N., and Savvas, D. (2006). Comparative effects of $\mathrm{NaCl}$ and $\mathrm{CaCl}_{2}$ salinity on cucumber grown in a closed hydroponic system. HortSci. 41, 437-441.

Turhan, A., Ozmen, N., Serbeci, M.S., and Seniz, V. (2011). Effects of grafting on different rootstocks on tomato fruit yield and quality. Hortic. Sci. 38, 142-149.

Verzera, A., Dima, G., Tripodi, G., Condurso, C., Crinò, P., and Romano, D. (2014). Aroma and sensory quality of honeydew melon fruits (Cucumis melo L. subsp. melo var. inodorus H. Jacq.) in relation to different rootstocks. Sci. Hortic. 169, 118-124. https://doi. org/10.1016/j.scienta.2014.02.008.

Vinkovic-Vrcek, I., Samobor, V., Bojic, M., Medic-Saric, M., Vukobratovic, M., Erhatic, R., Horvat, D., and Matotan, Z. (2011). The effect of grafting on the antioxidant properties of tomato (Solanum lycopersicum L.). Spanish J. Agric. Res. 9, 844-851. https://doi. org/10.5424/sjar/20110903-414-10.

Voogt, W. (1989). K/Ca with butterhead lettuce growth in recirculating water. Proc. $7^{\text {th }}$ Intern. Congr. Soilless Culture, Flevohof, 1988 (Wageningen, the Netherlands: ISOSC), p. 469-482.

Wang, X., Ouyang, Y., Liu, J., Zhu, M., Zhao, G., Bao, W., and Hu, F.B. (2014). Fruit and vegetable consumption and mortality from all causes, cardiovascular disease, and cancer: systematic review and dose-response meta-analysis of prospective cohort studies. BMJ 349, 1-14. https://doi.org/10.1136/bmj.g4490.

Wu, M., and Kubota, C. (2008a). Effects of high electrical conductivity of nutrient solution and its application timing on lycopene, chlorophyll and sugar concentrations of hydroponic tomatoes during ripening. Sci. Hortic. 116, 122-129. https://doi.org/10.1016/j. scienta.2007.11.014.

Wu, M., and Kubota, C. (2008b). Effects of electrical conductivity of hydroponic nutrient solution on leaf gas exchange of five greenhouse tomato cultivars. HortTechnol. 18, 271-277.

Wu, M., Buck, J.S., and Kubota, C. (2004). Effects of nutrient solution EC, plant microclimate and cultivars on fruit quality and yield of hydroponics tomatoes (Lycopersicon esculentum). Acta Hortic. 659, 541-547. https://doi.org/10.17660/actahortic.2004.659.70.

$\mathrm{Xu}$, C.Q., Li, T.L., and Qui, H.Y. (2006). Effects of grafting on development, carbohydrate content, and sucrose metabolizing enzymes activities of muskmelon fruit. Acta Hortic. Sinica 33, 773778.

Yarsi, G., and Sari, N. (2012). Determination of aroma compounds of grafted and ungrafted Galia C8 melon cultivar in greenhouse growing. In Cucurbitaceae 2012. Proceedings of the $X^{\text {th }}$ EUCARPIA Meeting on Genetics and Breeding of Cucurbitaceae, Antalya, Turkey, October 15-18, 2012 (University of Cukurova, Ziraat Fakultesi), p. $415-420$.

Zhou, X., Wu, Y., Chen, S., Chen, Y., and Zhang, W. (2014). Using Cucurbita rootstock to reduce Fusarium wilt incidence and increase fruit yield and carotenoid content in oriental melons. HortSci. 49, 1365-1369. 
Received: Oct. 17, 2017

Accepted: May 18, 2018

Addresses of authors:

N. Gruda ${ }^{1, *}$, D. Savvas ${ }^{2}$, G. Colla ${ }^{3}$ and Y. Rouphael ${ }^{4}$

${ }^{1}$ Division of Horticultural Sciences, Institute of Plant

Sciences and Resource Conservation, University of Bonn,

Bonn, Germany

${ }^{2}$ Laboratory of Vegetable Production, Agricultural

University of Athens, Athens, Greece

${ }^{3}$ Department of Agricultural and Forestry Sciences,

University of Tuscia, Viterbo, Italy

${ }^{4}$ Department of Agricultural Sciences, University of Naples

Federico II, Portici, Italy

* Corresponding author; E-mail: ngruda@uni-bonn 